\title{
A computational study on structural barrier to vertical spread of window spill plume along building exterior façade under external wind
}

\author{
Nan ZHAO \\ The Chinese People's Armed Police Forces Academy \\ Langfang, China \\ znamy119@163.com
}

\begin{abstract}
External wind is one of the major factors that influence the spread of fire along building exterior facade in high-rise buildings. Fire simulation experiments are conducted .First, under two circumstances of low-speed and high-speed side-blown wind, observing barrier of window spill plume along building exterior facade under different dimensions of windows, windowsill walls and balconies. Then the correlation between smoke temperature near the exterior facade and dimensions of window, windowsill wall and balcony is obtained by numerical fitting and dimensional analyses. The correlation indicates that, on low-speed side-blown wind, spill plume spreading diagonal up downwind, balcony width plays a leading barrier; on high-speed side-blown wind, spill plume horizontal spreading downwind, balcony extension plays a leading barrier.
\end{abstract}

Keywords- window spill plume; window; windowsill wall; balcony; barrier; external wind

\section{INTRODUCTION}

In case of fire, the major results of powerful external wind forces acting on high-rise building are the enhancement of the rapid fire spread along the building exterior facade. In recent years, there were many serious urban high-rise building fire incidents owning to the rapid spread of fire along the building exterior façade. These fire accidents caused significant threats to urban public safety.

On February 9 2009, north building exterior facade of CCTV's new address on fire, the fire spread rapidly and eventually ignited the whole building. The fire caused one firemen sacrificed, 7 persons been injured, more than 6000 nearby residents transferred, direct economic loss of $6 \sim 7$ billion.

In the last 50 years, there were already several works done on the topic of the spread of fire along building exterior façade and the knowledge achieved in these works has been applied to practice of the building fire safety design. A dimensionless temperature distribution along the trajectory axes of the plume ejected from windows was proposed by Yokio ${ }^{[1]}$. Himoto et al. ${ }^{[2]}$ developed a model to predict the trajectory of windows flame ejected from a fire compartment utilizing reduced scale experiments. The experimental of Suzuki et al. ${ }^{[3]}$ used a $1 / 7$ th scale model to represent a multilevel apartment complex to determine the effective use of balconies to reduce fire spread. John H. Mammoser and Francine Battaglia ${ }^{[4]}$ use computational fluid dynamics to research effects of type and elongation of balcony on window spill plume along building exterior facade. They concluded that: among four balconies types, that balcony, without brick retaining walls and with open on both sides, has the most obvious barrier effect on the spread of window spill plume. Fire experiments of F.Tang and L.H.Hu ${ }^{[5]}$ were carried out in a scale model, consisting of a $0.8 \mathrm{~m}$ cubic fire compartment with six window like geometries and an attached $3 \mathrm{~m}$ (wide) $\times 5 \mathrm{~m}$ (high) façade wall. They found the relationship between window size and flame height and of window spill plume along building exterior facade.

However, the behavior of window flame is affected by external wind when the building is on fire. Most of the existing researches were carried out using compartment only with a single opening on one of the vertical walls. In such a condition, the effect of external wind is not been considered, and so are the other structural barrier factors, such as windowsill walls and balconies.

In this study, we investigate into the effect of size of the balcony, height of the windowsill wall and size of the window on spread of window spill plume under different external wind conditions in order to find the optimization technology and program to control window spill plume at open of building exterior facade.

\section{FIRE MODEL AND CONDITIONS}

\section{A. Numerical formulation}

In this paper, FDS was used. Usually, large-eddy simulation is selected to numerical simulation of fire ${ }^{[6]}$.

\section{B. Building geometry}

The numerical simulation domain contained a fire floor and one floor above, two rooms were located on each floor, each room was $4 \mathrm{~m}$ tall by $4 \mathrm{~m}$ wide by $4 \mathrm{~m}$ deep and had one French window. Horizontal balconies extended below each window. According to the research of John H.Mammoser and Francine Battaglia on the geometrical shape of the balcony ${ }^{[4]}$, the best effect to barrier the vertical spread of window spill is the balcony without brick retraining walls and with open on both sides. So this balcony was adopted in this paper. Figs. 1 and Figs. 2 show the building geometry for the numerical simulation. The height of the window is $\mathrm{H}$; the width of the window is w; the height of the windowsill wall in every storey is L; the elongation of the balcony is $\mathrm{d}$; the width of the balcony is $\mathrm{p} ; \mathrm{H}+\mathrm{L}=4 \mathrm{~m}$. 


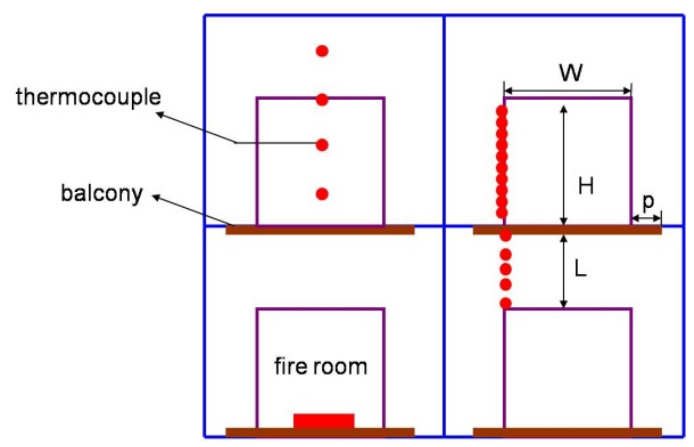

Fig1. The front view of simulation model

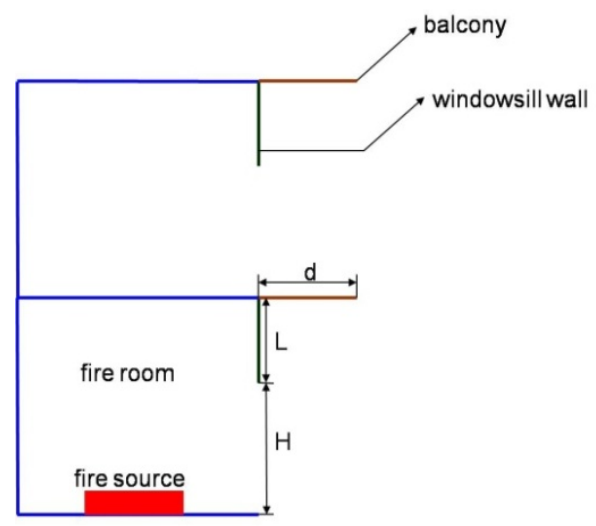

Fig2. The side view of simulation model

The fire room was on the ground floor. One $2 \mathrm{~m} 2$ manually controlled methane gas burner $(0.2 \mathrm{~m}$ tall by $1 \mathrm{~m}$ wide by $2 \mathrm{~m}$ deep) provided the fire. The fire source was located in the centre of the fire room The selection method[7] of heat release rate of the fire source is as shown in Table 1. The ground floor area of the fire room was $16 \mathrm{~m}^{2}$, heat release rate of the fire source was conducted at 6MW.

There were three different thermocouple trees located near the external facade wall surface (see Fig.1). One thermocouple tree, consisting of four thermocouples, was installed in the middle of the room right above the fire room. The highest thermocouple was $0.8 \mathrm{~m}$ below the ceiling and the vertical separation distance between the thermocouples was $0.8 \mathrm{~m}$. The second thermocouple tree, having nine thermocouples, was placed at intervals of $0.1 \mathrm{~m}$ near the wall surface of the room on the right top of the fire room. The highest thermocouple was near the top left corner of the room window. The third thermocouple tree, consisting of five thermocouples, was installed near the wall surface of the room next to the fire room. The highest thermocouple was near the top left corner of the room window and the vertical separation distance between the thermocouples was $0.2 \mathrm{~m}$.
Based on the statistical data of urban wind speed in recent years, the wind speed at $10 \mathrm{~m}$ height is set to $3 \mathrm{~m} / \mathrm{s}$. According to the correlation between wind speed and building height, the wind speed at $100 \mathrm{~m}$ height is set to $6 \mathrm{~m} / \mathrm{s}$. Therefore, we selected low-speed wind $(3 \mathrm{~m} / \mathrm{s})$ and highspeed wind $(6 \mathrm{~m} / \mathrm{s})$ as two different external wind conditions of high-rise buildings in fire simulation experiments. The wind direction is set to left side wind.

TABLE I. THE SELECTION OF HEAT RELEASE RATE OF FIRE SOURCE

\begin{tabular}{|c|c|}
\hline Fire place & Heat release rate $\left(\mathrm{kW} / \mathrm{m}^{2}\right)$ \\
\hline Theo bald (industrial) & 260 \\
\hline Law (offices) & 290 \\
\hline Hansell \& Morgan & \\
\hline & \\
\hline & \\
\hline
\end{tabular}

This research selected five different sizes of elongation of the balcony (respectively, $\mathrm{d}=0.4 \mathrm{~m}, 0.6 \mathrm{~m}, 0.8 \mathrm{~m}, 1.0 \mathrm{~m}, 1.2 \mathrm{~m}$ ), five different sizes of height of the windowsill wall (respectively, $\mathrm{L}=0.8 \mathrm{~m}, 1.0 \mathrm{~m}, 1.2 \mathrm{~m}, 1.4 \mathrm{~m}, 1.6 \mathrm{~m}$ ), five different sizes of width of the balcony (respectively, $p=0 \mathrm{~m}$ 、

$0.1 \mathrm{~m} 、 0.2 \mathrm{~m} 、 0.3 \mathrm{~m} 、 0.4 \mathrm{~m})$, five different sizes of width of the window (respectively, $w=1.2 \mathrm{~m} 、 1.6 \mathrm{~m} 、 2.0 \mathrm{~m} 、 2.4 \mathrm{~m}$ 、 $2.8 \mathrm{~m}$ ). Using conventional means, 125 sets of test needed to be done separately under low-speed side-blow wind and high-speed side-blow wind. So we decided to use orthogonal experimental method " $\mathrm{L}_{25}(56)$ ". As a result, tests were carried out at only 25 different conditions separately, as shown in Table 2.

According to the research of Zhang Qing-wen and Zhang He-ping ${ }^{[8]}$, $6 \mathrm{~mm}$ thick float glass cracking at high temperature, the minimum temperature on the surface of exposed glass is $70^{\circ} \mathrm{C}$, which is hazardous temperature in John H. Mammoser and Francine Battaglia's research. Therefore $70{ }^{\circ} \mathrm{C}$ was selected as the critical hazardous temperature in this research.

TABLE II. THE LIST OF 25 SETS OF TEST UNDER DIFFERENT EXTERNAL WIND CONDITION

\begin{tabular}{|c|c|c|c|c|}
\hline & $d(\mathrm{~m})$ & $L(\mathrm{~m})$ & $p(\mathrm{~m})$ & $w(\mathrm{~m})$ \\
\hline 1 & 0.4 & 0.8 & 0 & 1.2 \\
\hline 2 & 0.4 & 1.0 & 0.1 & 1.6 \\
\hline 3 & 0.4 & 1.2 & 0.2 & 2.0 \\
\hline 4 & 0.4 & 1.4 & 0.3 & 2.4 \\
\hline 5 & 0.4 & 1.6 & 0.4 & 2.8 \\
\hline
\end{tabular}




\begin{tabular}{|c|c|c|c|c|}
\hline 6 & 0.6 & 0.8 & 0.1 & 2.0 \\
\hline 7 & 0.6 & 1.0 & 0.2 & 2.4 \\
\hline 8 & 0.6 & 1.2 & 0.3 & 2.8 \\
\hline 9 & 0.6 & 1.4 & 0.4 & 1.2 \\
\hline 10 & 0.6 & 1.6 & 0 & 1.6 \\
\hline 11 & 0.8 & 0.8 & 0.2 & 2.8 \\
\hline 12 & 0.8 & 1.0 & 0.3 & 1.2 \\
\hline 13 & 0.8 & 1.2 & 0.4 & 1.6 \\
\hline 14 & 0.8 & 1.4 & 0 & 2.0 \\
\hline 15 & 0.8 & 1.6 & 0.1 & 2.4 \\
\hline 16 & 1.0 & 0.8 & 0.3 & 1.6 \\
\hline 17 & 1.0 & 1.0 & 0.4 & 2.0 \\
\hline 18 & 1.0 & 1.2 & 0 & 2.4 \\
\hline 19 & 1.0 & 1.4 & 0.2 & 2.8 \\
\hline 20 & 1.0 & 1.6 & 0.1 & 1.2 \\
\hline 21 & 1.2 & 0.8 & 0.4 & 2.4 \\
\hline 22 & 1.2 & 1.0 & 0 & 2.8 \\
\hline 23 & 1.2 & 1.2 & 0.1 & 1.2 \\
\hline 24 & 1.2 & 1.4 & 0.2 & 1.6 \\
\hline 25 & 1.2 & 1.6 & 0.3 & 2.0 \\
\hline
\end{tabular}

\section{RESULTS AND DISCUSSION}

\section{A. Effect of structural barrier under low-speed side-blown wind}

The numerical results for temperatures along the facade illustrate the effect of the structural barrier. Table. 3 shows the maximum temperatures along the facade of the room right above the fire room(T) and the room on the top right $\left(T^{\prime}\right)$ in 25 sets of numerical experiments.

TABLE III. THE TEMPERATURE IN 25 SETS OF TEST UNDER LOW-SPEED SIDE-BLOWN WIND

\begin{tabular}{|c|c|c|c|c|c|c|}
\hline $\begin{array}{l}\text { Factor } \\
\text { Number }\end{array}$ & $d)(\mathrm{m}$ & $L \quad(\mathrm{~m}$ & $p \quad(\mathrm{~m}$ & w) $(\mathrm{m}$ & $T,\left({ }^{\circ} \mathrm{C}\right.$ & $\begin{array}{l}T^{\prime} \quad( \\
\left.{ }^{\circ} \mathrm{C}\right)\end{array}$ \\
\hline 1 & 0.4 & 0.8 & 0 & 1.2 & 26 & 68 \\
\hline 2 & 0.4 & 1.0 & 0.1 & 1.6 & 26 & 73 \\
\hline 3 & 0.4 & 1.2 & 0.2 & 2.0 & 26 & 94 \\
\hline 4 & 0.4 & 1.4 & 0.3 & 2.4 & 26 & 100 \\
\hline
\end{tabular}

\begin{tabular}{|c|c|c|c|c|c|c|}
\hline 5 & 0.4 & 1.6 & 0.4 & 2.8 & 26 & 55 \\
\hline 6 & 0.6 & 0.8 & 0.1 & 2.0 & 26 & 78 \\
\hline 7 & 0.6 & 1.0 & 0.2 & 2.4 & 26 & 145 \\
\hline 8 & 0.6 & 1.2 & 0.3 & 2.8 & 26 & 127 \\
\hline 9 & 0.6 & 1.4 & 0.4 & 1.2 & 26 & 100 \\
\hline 10 & 0.6 & 1.6 & 0 & 1.6 & 26 & 109 \\
\hline 11 & 0.8 & 0.8 & 0.2 & 2.8 & 26 & 163 \\
\hline 12 & 0.8 & 1.0 & 0.3 & 1.2 & 26 & 59 \\
\hline 13 & 0.8 & 1.2 & 0.4 & 1.6 & 26 & 81 \\
\hline 14 & 0.8 & 1.4 & 0 & 2.0 & 26 & 115 \\
\hline 15 & 0.8 & 1.6 & 0.1 & 2.4 & 26 & 116 \\
\hline 16 & 1.0 & 0.8 & 0.3 & 1.6 & 26 & 112 \\
\hline 17 & 1.0 & 1.0 & 0.4 & 2.0 & 26 & 133 \\
\hline 18 & 1.0 & 1.2 & 0 & 2.4 & 26 & 174 \\
\hline 19 & 1.0 & 1.4 & 0.2 & 2.8 & 26 & 206 \\
\hline 20 & 1.0 & 1.6 & 0.1 & 1.2 & 26 & 105 \\
\hline 21 & 1.2 & 0.8 & 0.4 & 2.4 & 26 & 151 \\
\hline 22 & 1.2 & 1.0 & 0 & 2.8 & 26 & 254 \\
\hline 23 & 1.2 & 1.2 & 0.1 & 1.2 & 26 & 98 \\
\hline 24 & 1.2 & 1.4 & 0.2 & 1.6 & 26 & 84 \\
\hline 25 & 1.2 & 1.6 & 0.3 & 2.0 & 26 & 143 \\
\hline
\end{tabular}

Using the undetermined coefficient method, determine the effect of $\mathrm{d}, \mathrm{L}, \mathrm{p}$ and $\mathrm{w}$ on $\mathrm{T}$ '. The critical hazardous temperature is $70^{\circ} \mathrm{C}$ in this research. $\mathrm{T}^{\prime}-70>0$ represents $\mathrm{T}$ exceeds the risk value; $T^{\prime}-70<0$ represents $T^{\prime}$ does not exceed the risk value. Set the relationship between the $d, L, p, w$ and T as:

$$
T^{\prime}-70=c_{1} d+c_{2} L+c_{3} p+c_{4} w
$$

Converting to a matrix form, and finally, the relationship is got.

$$
T^{\prime}-70=62.6 d-46.3 L-101.6 p+38.0 w
$$

We correlate Table.3 with Eq.(2), we can conclude that, under low-speed side-blown wind, spill plume spreading diagonal up downwind, the width of balcony and the windowsill wall play different degrees of barrier effect on vertical spread of window spill plume along building exterior facade, on the contrary, the elongation of the balcony and the width of the window play different degrees of promotion effect ,the width of balcony playing dominant barrier effect. 


\section{B. Effect of structural barrier under high-speed side- blown wind}

Table.4 shows $\mathrm{T}, \mathrm{T}^{\prime}$ and the maximum temperatures along the facade of the room next to the fire room ( $\left.\mathrm{T}^{\prime \prime}\right)$ in 25 sets of numerical experiments.

TABLE IV. THE TEMPERATURE IN 25 SETS OF TEST UNDER HIGH-SPEED SIDE-BLOWN WIND

\begin{tabular}{|c|c|c|c|c|c|c|c|}
\hline $\begin{array}{c}\text { Factor } \\
\text { Number }\end{array}$ & $\begin{array}{c}d \\
(\mathrm{~m}) \\
\end{array}$ & $\begin{array}{c}L \\
(\mathrm{~m}) \\
\end{array}$ & $p(\mathrm{~m})$ & $w(\mathrm{~m})$ & $T\left({ }^{\circ} \mathrm{C}\right)$ & $\begin{array}{c}T^{\prime} \\
\left({ }^{\circ} \mathrm{C}\right) \\
\end{array}$ & $\begin{array}{l}T^{\prime \prime} \\
(\quad)\end{array}$ \\
\hline 1 & 0.4 & 0.8 & 0 & 1.2 & 26 & 70 & 158 \\
\hline 2 & 0.4 & 1.0 & 0.1 & 1.6 & 26 & 68 & 195 \\
\hline 3 & 0.4 & 1.2 & 0.2 & 2.0 & 26 & 87 & 242 \\
\hline 4 & 0.4 & 1.4 & 0.3 & 2.4 & 26 & 95 & 247 \\
\hline 5 & 0.4 & 1.6 & 0.4 & 2.8 & 26 & 35 & 237 \\
\hline 6 & 0.6 & 0.8 & 0.1 & 2.0 & 26 & 69 & 231 \\
\hline 7 & 0.6 & 1.0 & 0.2 & 2.4 & 26 & 133 & 260 \\
\hline 8 & 0.6 & 1.2 & 0.3 & 2.8 & 26 & 108 & 266 \\
\hline 9 & 0.6 & 1.4 & 0.4 & 1.2 & 26 & 87 & 206 \\
\hline 10 & 0.6 & 1.6 & 0 & 1.6 & 26 & 90 & 212 \\
\hline 11 & 0.8 & 0.8 & 0.2 & 2.8 & 26 & 134 & 215 \\
\hline 12 & 0.8 & 1.0 & 0.3 & 1.2 & 26 & 55 & 182 \\
\hline 13 & 0.8 & 1.2 & 0.4 & 1.6 & 26 & 67 & 171 \\
\hline 14 & 0.8 & 1.4 & 0 & 2.0 & 26 & 78 & 197 \\
\hline 15 & 0.8 & 1.6 & 0.1 & 2.4 & 26 & 99 & 242 \\
\hline 16 & 1.0 & 0.8 & 0.3 & 1.6 & 26 & 103 & 217 \\
\hline 17 & 1.0 & 1.0 & 0.4 & 2.0 & 26 & 104 & 268 \\
\hline 18 & 1.0 & 1.2 & 0 & 2.4 & 26 & 157 & 249 \\
\hline 19 & 1.0 & 1.4 & 0.2 & 2.8 & 26 & 185 & 260 \\
\hline 20 & 1.0 & 1.6 & 0.1 & 1.2 & 26 & 94 & 301 \\
\hline 21 & 1.2 & 0.8 & 0.4 & 2.4 & 26 & 112 & 176 \\
\hline 22 & 1.2 & 1.0 & 0 & 2.8 & 26 & 237 & 221 \\
\hline 23 & 1.2 & 1.2 & 0.1 & 1.2 & 26 & 76 & 182 \\
\hline 24 & 1.2 & 1.4 & 0.2 & 1.6 & 26 & 68 & 165 \\
\hline 25 & 1.2 & 1.6 & 0.3 & 2.0 & 26 & 59 & 198 \\
\hline
\end{tabular}

Using the undetermined coefficient method, determine the effect of $d, L, p$ and $w$ on $T^{\prime \prime} .70^{\circ} \mathrm{C}$ is the critical hazardous temperature in this research. $\mathrm{T}^{\prime \prime}-70>0$ represents $\mathrm{T}$ exceeds the risk value; $T^{\prime \prime}-70<0$ represents $T$ " does not exceed the risk value. Set the relationship between the d, L, $\mathrm{p}, \mathrm{w}$ and $\mathrm{T}$ as:

$$
T^{\prime \prime}-70=e_{1} d+e_{2} L+e_{3} p+e_{4} w
$$

Converting to a matrix form, and finally, the

relationship is got.

$$
T^{\prime \prime}-70=-28.3 d+5.2 L-25.0 p+15.9 w
$$

We correlate Table.4 with Eq.(4), we can conclude that, under high-speed side-blown wind, spill plume horizontal spreading downwind, the width of balcony and the elongation of the balcony play different degrees of barrier effect on vertical spread of window spill plume along building exterior facade, on the contrary, the windowsill wall and the width of the window play different degrees of promotion effect, the elongation of the balcony playing dominant barrier effect.

\section{CONCLUSIONS}

In this study, a series of full-scale numerical investigation was carried out. The vertical spread of window spill plume along high-rise building exterior facade under different external wind situations was researched with different dimensions of window, windowsill wall and balcony. The correlation between smoke temperature near the exterior facade and dimensions of window, windowsill wall and balcony is obtained, and then the following conclusions can be drawn:

(1)Under the circumstance of low-speed side-blown wind, spill plume spread diagonal up downwind and was more likely to endanger the room above the fire room in along-wind direction. The width of balcony and the windowsill wall play different degrees of barrier effect on vertical spread of window spill plume along building exterior facade. on the contrary, the elongation of the balcony and the width of the window play different degrees of promotion effect .The width of balcony playing dominant barrier effect.

(2)Under the circumstance of high-speed side-blown wind, spill plume horizontal spreading downwind and was likely to endanger the room next to the fire room in alongwind direction. The width of balcony and the elongation of the balcony play different degrees of barrier effect on vertical spread of window spill plume along building exterior facade. On the contrary, the windowsill wall and the width of the window play different degrees of promotion effect. The elongation of the balcony playing dominant barrier effect.

\section{ACKNOWLEDGMENT}

This work was supported by a grant from the Major State Basic Research Development Program of China (973 Program) (No.2012CB719702-3) 


\section{REFERENCES}

[1] [1] Yokoi, S., 1960. Study on the prevention of fire spread caused by hot upward current. Japan, Report 34, Report of the building research institute.

[2] [2] Himoto, K., Tsuchihashi, T., Tanaka, Y., 2009. Modeling thermal behaviors of window flame ejected from a fire compartment. Fire safety journal 44, pp. 30-240.

[3] [3] Suzuli, T., Sekizawa, A., Yamada, T., YAnai, E., Satoh, H., Kurioka, H., Kimura, Y., 2001. An experimental study of ejected flames of a high-rise building. Technical report, National Research Institute of Fire and Disaster, Japan, pp. 363-373.
[4] [4] John, H., Francine, B., 2004. A computational study on the use of balconies to reduce flame spread in high-rise apartment fires. Fire safety journal 39, pp. 277-296.

[5] [5] Tang, F., Hu, L.H., 2012. Experimental study on flame height and temperature profile of buoyant window spill plume from an underventilated compartment fire. International journal of Heat and Mass transfer 55, pp. 93-101.

[6] [6] Kevin, M., Simo, H., Jason, F., Fire Dynamics Simulator (version 5) Technical Reference Guide. NIST Special Publication, p. 1018-5.

[7] [7] Predicting the Rate of Heat Release of Fires.

[8] [8] Feng, R., 2006. Studies on the validity of pressurization system in high-rise buildings. Thesis for the Degree of Master of Science in University of Science and Technology of China, pp.46-77. 